Arhe XVIII, 36/2021

UDK 1 Leibniz G.W.

004.252

DOI https://doi.org/10.19090/arhe.2021.36.129-152

Originalni naučni rad

Original Scientific Article

\author{
АЛЕКСАНДАР ОСТОЈИЋ ${ }^{1}$ \\ Универзитет у Београду, Институт за филозофију и друштвену теорију / \\ Универзитет у Новом Саду, Економски факултет у Суботици
}

\title{
ЛАЈБНИЦ И SOUVENIR VIRTUAL ${ }^{2}$
}

Сажетак: Рад настоји да испита Лајбницов концепт виртуалне меморије, те да одреди њену улогу унутар монадолошке концепције света. Лајбницов појам меморије је свакако вишезначан, што ће се у раду увидети, кроз експликацију места у Лајбницовим текстовима, на којима је меморија различито одређена. Прецизније, видећемо да Лајбниц разликује различите функције унутар појма меморије и да их у складу са тим различито и именује, а да су ипак сви они обухваћени унутар виртуалне меморије која чини како онтолошки, тако и епистемолошки основ Лајбницовог универзума. У првом делу рада изложићемо начелне монадолошке поставке, те разлоге због којих виртуална меморија има великог удела у њима. Затим ћемо испитати места на којима Лајбниц пише о меморији, настојећи да их, поред разлика које постоје између тих одређења, објединимо унутар нашег разумевања виртуалне меморије. Да би се истакао значај новина које Лајбниц уноси у разумевање овог феномена, биће неопходно ставити такво разумевање наспрам традиције, унутар које ћемо се фокусирати на Аристотела. На крају, видећемо зашто је таква поставка меморије, коју претпостављамо, нераздвојна од свих видова увећања знања код Лајбница, односно представља нужну структуру на којој се знање темељи.

Кључне речи: Лајбниц, меморија, монадологија, памћење, виртуално, знање, Аристотел

\footnotetext{
1 E-mail адреса аутора: aleksandar.ostojic@instifdt.bg.ac.rs; aleksandar.ostojic@ef.uns.ac.rs

2 Овај рад је реализован уз подршку Министарства просвете, науке и технолошког развоја Републике Србије према Уговору о реализацији и финансирању научноистраживачког рада.
} 
Проблем меморије заузима значајно место у Лајбницовој мисли, те стога чуди што му се у интерпретацијама не поклања толико пажње. Неколико тумачења ипак адресирају овај проблем, а уобичајено му се приступа у једном од ова два аспекта. Један начин да се приступи Лајбницовом појму меморије је кроз епистемолошку призму: разум или ум у сваком покушају закључивања, или уопште процеса мишљења, морају да се служе меморијом, стога је њена улога у доласку до знања унеколико очигледна. Меморија се испоставља као услов могућности разумског делања, јер она је услов могућности да се идеје (односно перцепције истих) повезују. $\mathrm{Ca}$ друге стране, меморија има своју метафизичку улогу у конституисању Лајбницовог универзума. Веза између монада и између идеја и концепата које оне деле заснива се на меморији. Тако и „престабилирана хармонија”, на којој почива структура Лајбницовог универзума, у себи већ обухвата меморију, како ће се у раду и показати.

Интерпретација унутар овог рада се неће искључиво водити ниједним од два уобичајена приступа сагледавања меморије у Лајбницовој филозофији: епистемичким и метафизичким. За нас, релација меморије и знања подразумева јединство једног и другог погледа, епистемолошко и метафизичко су испреплетани и међусобно условљени, како у овом раду, тако и код самог Лајбница. Ми ћемо се, дакле, водити јединственим приступом у покушају да лоцирамо меморију и знање унутар целости Лајбницове мисли. За такав задатак неопходно је образложити и појаснити почетне наводе, како би се повратно пружио неопходан легитимитет оваквом приступу, што захтева пар основних напомена о Лајбницовом метафизичком систему. Поврх тога, како би се Лајбницово разумевање меморије и значај истог адекватно истакао, потребно је позиционирати га, стављајући га наспрам других (одабраних) концепција меморије унутар дуге традиције разумевања ового феномена - почевши од њеног митолошког извора - Мнемосине. 


\section{МОНАДОЛОГИЈА И ВИРТУАЛНА МЕМОРИЈА - ПРИСТУП БЕСКОНАЧНОМ ЗНАЮУ}

По Лајбницу, Универзум се састоји од бесконачног броја индивидуалних супстанција, које он назива „монадама”. ${ }^{3}$ Монаде немају делове, те стога нису дељиве, а не поседују ни протежност ни форму. Такође, оне не могу постепено умрети (угинути), нити постепено настати - створене су одједном од стране Бога и стога једини начин на који могу нестати није природни процес, већ уништење (једино од стране Бога). Лајбниц даље наводи да „нема начина на који би се објаснило како би се монада могла подругојачити, или променити у својој унутрашњости од каквог другог створења"4, јер, како каже толико пута понављана мисао, „Монаде немају прозора, кроз које би нешто у њих могло ући, или из њих изаћи." Међутим, то нипошто не значи да се монаде не мењају, јер главна одлика света јесте промена - те монаде непрекидно мењају „стања” у којима се налазе. Ова стања Лајбниц карактерише као „перцепције”, док њихову тежњу ка промени стања назива „апетиција". ${ }^{6}$ За наш проблем меморије и знања кључно је, међутим, следеће: ниједна монада није иста, али у својој перцепцији, монада је нека врста огледала, те она „одражава” читав универзум, који се управо састоји од монада. Лајбниц ће рећи да свака монада изражава стање свих осталих монада у датом тренутку - ово поистовећивање мноштва и јединства представља дословно преклапање микро и макрокосмоса - како Лајбниц каже: „свака монада је читав универзум у малом”7. Помиње се да је при

\footnotetext{
${ }^{3}$ Leibniz, G. W., „Rasprava o metafizici“, y: Izabrani filozofski spisi, стр. 114115. Lajbnic, G. V., Monadologija, prevod i komentari: Dušan Nedeljković, Kultura, Beograd, 1957. стр. 49-53.

${ }^{4}$ Lajbnic, G. V., Monadologija, стр. 49.

${ }^{5}$ Исто.

${ }^{6}$ Неке од ових навода детаљније ћемо анализирати касније, овде се нацрт система даје само како би меморија могла да се позиционира унутар њега.

${ }^{7}$ Mates, Benson, The philosophy of Leibniz, Metaphysics and Language, стр. 37.
} 
извођењу оваквог закључка на Лајбница велики утицај имало Левенхуково откриће, али није ни Лајбниц први који ће тврдити да постоје „светови у световима”, на шта упућује следећи цитат: „Треба прихватити, како су запазили реномирани микрографисти Кирхер и Хук, да ће већину квалитета на које смо осетљиви у већим стварима, вешт опажач открити у пропорцији у мањим стварима. А ако ово иде до бесконачности - сваки атом ће бити бесконачне врсте, попут некаквог света, и постојаће светови унутар светова до бесконачности."

Монада, дакле, перципира стања свих осталих монада у датом тренутку, а Лајбниц ће при том тврдити да је свако стање монаде природна последица њених прошлих и будућих стања („садашњост је бременита будућношћу”9); одатле следи да свака монада у сваком тренутку у себи садржи све што се догодило и што ће се догодити. ${ }^{10}$ Приметимо да се у једном моменту помиње да монада перципира све остале монаде, а у другом да их изражава. За сада је довољно разумети да, премда Лајбниц има засебне дефиниције за перцепцију и за изражавање, и да су стога то два различита концепта, у његовој монадологији монада изражава тако што периипира. Идеја јесте изражена на начин на који је монада перципира. Реч је о два нимало једноставна термина у Лајбницовом систему; проблемом изражсавања бавићемо се у следећем поглављу, а што се тиче периепиије, Лајбницова подела исте сложенија је од оне његових савременика (Декарт, Спиноза); стога је овде потребно направити кратак осврт на ту поделу, на коју ћемо се враћати касније.

Према Лајбницу, спознаја може бити тамна или јасна; јасна je, пак, збркана или разговетна, а разговетна је или адекватна или инадекватна, симболична или интуитивна. ${ }^{11}$ Велика новина у

\footnotetext{
${ }^{8}$ Leibniz, Gottfried Wilhelm, Philosophical papers and letters, ed. Loemker, стр. 338.

${ }^{9}$ Lajbnic, G. V., Monadologija, стр. 52.

${ }^{10}$ Исто.

${ }^{11}$ Leibniz, G. W., „Razmatranja o spoznaji, istini i idejama“, y: Izabrani filozofski spisi, стр. 3.
} 
односу на савременике јесте што чулна спознаја за Лајбница може да буде јасна, те самим тим она није погрешна: уколико не умем да изнесем дефиницију предмета набрајајући његове одлике (карактеристике), по чему бих га разликовао од других предмета, ја имам неразговетну, односно збркану спознају, али она је и даље јасна (довољно је испунити захтев препознавања). Вратимо се сада на тврдњу да монада у сваком моменту перципира све остале монаде, и обратимо пажњу на резоновање Мејтса:

„Дакле, говорећи да у сваком тренутку стање сваке монаде изражава стања свих осталих, Лајбниц само тврди да је, с обзиром на потпуно знање о стању било које одређене монаде у било које одређено време, довољно проницљив ум могао да прочита стање било које друге монаде у то време. Даље, свако стање монаде на сличан начин одражава сва прошла и будућа стања те монаде. Сходно томе, ако би човек у потпуности знао стање било које монаде у било ком тренутку и ако би имао адекватне логичке моћи, могао би у сваком тренутку да утврди стања те и свих осталих монада. То је смисао у којем је 'све повезано са свиме'."12

Све је, дакле, са свиме повезано, а у складу са претходно реченим, разлика између више различитих израза јесте разлика у перцепцији или спознаји, али не и у садржају који се перципира. Покушајмо да сумирамо речено. Свет се састоји од монада, које су створене од стране Бога, али и сам Бог је монада, рећи ће Лајбниц ${ }^{13}$, у потпуности савршена и првотна монада - али и даље монада, што значи да је Бог део монадолошког света. Постоји бесконачан број монада; Бог у себи обухвата ову бесконачност, односно јасно је види ${ }^{14}$, јер и Бог је монада која перципира све остале монаде. Али пошто свака монада перципира стања свих осталих монада

${ }^{12}$ Mates, Benson, The philosophy of Leibniz, Metaphysics and Language, стр. 38.

${ }^{13}$ Lajbnic, G. V., Monadologija, стр. 55.

${ }^{14}$ Премда је божанска перцепција увек јасна и разговетна, бесконачност остаје бесконачност, погледати: Leibniz, Gottfried Wilhelm. Logical Papers: A Selection, ed. Parkinson, стр. 109. 
(укључујући и Бога), свака монада мора да има приступ овој бесконачности, премда је не обухвата (не види јасно).

Уколико монаде перципирају бесконачност, а њихове једине карактеристике су перцепција и апетиција, да ли то значи да су и оне бесконачне? Лајбниц ће рећи: „Душа не може да развије све своје превоје, јер они иду у бесконачност"15. О томе говори и Миленковић, у предговору за „Набор”: „Душа је монада, а монада према речима самог Лајбница нема прозоре који гледају на споља. Ако је, пак, тако, о којој онда врсти бесконачности говоримо? Очигледно не о просторној, већ о бесконачности иманенције, или, што није сасвим исто, иманентној бесконачности набора." ${ }^{16}$ Ипак, треба бити опрезан са термином бесконачности. Могућности „извијања”, изражавања монаде, или онога што би она могла да захвати, јесу бесконачне, јер она путем перцепције дели садржај божанске монаде. Са друге стране, Лајбниц јасно напомиње да су монаде створене од стране Бога, што, уз хришћански контекст унутар ког Лајбниц пише, једноставно не дозвољава бесконачност монада. Међутим, знајући да он хвали Спинозину поделу бесконачности на три врсте, логично би било закључити да монаде нису бесконачне по себи, већ да су бесконачне по узроку. Лајбниц ипак има мало другачије виђење бесконачности и краја ${ }^{17}$ од

${ }^{15}$ Lajbnic, G. V., Monadologija, стр. 54.

${ }^{16}$ Milenković Ivan, „Predgovor“, u: Delez, Žil, Nabor: Lajbnic i barok, Fedon, Beograd, 2018.

17 Спиноза на две постојеће врсте бесконачности, бесконачно по себи и бесконачно по узроку, уводи и трећу, што ће Лајбницу управо бити повод за похвалу, а то је: бесконачно обухваћено границама. Не чуди да је ова подела блиска Лајбницу, имајући у виду да се његово развијање инфинитезималног рачуна базирало управо на изражавању или обухватању бесконачног низа, који тежи некој граници, али увек испоставља нови последњи члан. Лајбницу јесте блиско ово тумачење, и мада ћемо се у раду још дотицати аналогије са инфинитезималним рачуном, не желимо да улазимо у дебату да ли он своје виђење математике преноси на метафизику или обратно. За боље разумевање Лајбницовог односа између бесконачности и краја (бескрајности) погледати Leibniz, G. W., Philosophiscen Schriften, edited by: Gerhardt, C. I., vol. 7, Hildesheim, Berlin, 1965. I , стр. 137. 
Спинозе, и премда није конзистентан у употреби овог термина, сматрамо из више разлога да је уместо њега, у овом случају правилније користити термин бескрајност, који у нашем раду, између осталог, упућује и на бесконачну унутрашњост монаде (која је уз то „одраз” њене спољашности).

На тај начин, монада ипак у себи има бесконачни универзум, па тако и све истине о њему, али на начин диспозиције виртуално, рећи ће Лајбниц. ${ }^{18}$ Све монаде деле бескрајни садржај који перципирају, али га оне перципирају на различите начине, са тим да нису свесне већине својих перцепција - зато постоји тамно дно монаде. То тамно дно није актуализовано у знању или свести, „нити је разговетно доступно” 19 , али је доступно. Цео свет, са свим својим везама, ускладиштен је унутар монаде путем њених перцепција. У том свету будућност је најтешње повезана са прошлошћу, а јасност или нејасност унутрашњег садржаја истоветно се преноси и на њено изражавање - јер постоји безброј ситних и невидљивих кретања, ситних опажаја којих нисмо свесни, али које и даље опажамо и постоји „хиљаду знакова” путем којих се да видети „да су бесконачно много опажаја сваког трена у нама.”20 Све је дакле доступно, свеукупно знање је похрањено унутар виртуалности, а та виртуалност је, као и код богиње Мнемосине поље меморије.

\footnotetext{
${ }^{18}$ Може се помислити да се појам виртуално користи у новијем тумачењу Лајбница (између осталих присутан је и код Делеза) и да је реално виртуално нови облик старог пара актуално - могуће (да би се направила дистинкција у односу на Аристотелово разумевање ових термина; наиме, код Лајбница, за разлику од Аристотела, могућност надилази актуалност.) Међутим, Лајбниц у својим латинским списима употребљава управо реч virtualno која је у латинском синоним од речи insitus i znači: урођено, усађено, могућност уграђена од стане природе, природни потенцијал.

${ }^{19}$ Lajbnic, G. V., Novi ogledi o ljudskom razumu, стр. 65.

${ }^{20}$ Исто, стр. 9.
} 


\section{ЗНАЬЕ И МОГУЋНОСТ}

Окренимо се сада ка појму знања које произилази из претходно изложеног система. Лајбниц знање налази у везама између идеја, односно, ово је његова непосредна дефиниција знања, коју је лако утемељити уколико се позовемо на почетак књиге IV Нових огледа о људском разуму, где Филатет каже: „Сазнање није ништа друго до опажај везе између две наме идеје. Било да замишљамо, претпостављамо или пак верујемо, иста је ствар.” 21 Ничег новог у овој тврдњи нема што би заинтригирало иоле упућеног читаоца, не само зато што је Филатет у дијалогу задужен да износи Локово учење, већ зато што се, и пре Лока, сазнање које се налази у увиђању веза изражавало путем исказа, за који се онда утврђивала истинитост или неистинитост. Ипак, у Теофиловом одговору Филалету, наговештена је велику новина коју ће Лајбниц увести. Та новина не односи се на форму саме дефиниције знања, која дакле остаје иста, већ на детаљну експликацију појмова садржаних у овој дефиницији. Питања која Лајбниц поставља, а која у великој мери раскрштају са традицијом, представљајући својеврсну (р)еволуцију разумевања знања, јесу следећа: која је природа тих веза, како се оне уочавају, и како то на крају утиче на cаме идеје? Сваки од одговора, непосредно ће укључивати меморију.

Одговори на ова питања започињу од последњег развијањем и разјашњавањем појма неопходног да би се прича о знању и меморији уобличила у кохерентну целину - Реч је, наравно, о идејама. ${ }^{22}$ На почетку Нових огледа одмах је уочљива разлика (али и сличност) са Платоном, јер, идеје јесу урођене истине, али оне не

\footnotetext{
${ }^{21}$ Исто, стр. 315.

22 Када смо говорили од Декарту, Бекону и новој улози меморије у формирању метода, реч је управо била о томе да ја баратам са идејама унутар свог ума. У томе је и велика новина Логике Пор Ројала, управо зато што је реч о логици идеја. Погледати Popović, Una, „Logika ideja: Por Rojal i Dekartovo nasleđe“, y: Годишьак Филозофског факултета у Новом Саду, стр. 49-66.
} 
припадају никаквом интелигибилном свету, нити су есенције за себе, већ су диспозиције или могућности мишљења. ${ }^{23}$ Па тако налазимо: „Да би се знања, идеје или истине налазиле у нашем духу, није нимало неопходно да смо доиста актуелно мислили о њима. То су само природне склоности, тј. активне и пасивне способности и предиспозиције и нешто више од tabula rasa."24 Овако схватање идеја засновано је управо на монадолошком учењу.

Од своје дисертације De Arte Combinatoria, Лајбниц је настојао да изнађе неку врсту универзалног приступа знањ ${ }^{25}$. Да би универзални приступ могао постојати, неопходно је да се знање обухвати, да се на било који начин увеже. Souvenire virtual или виртуална меморија унутар Лајбницове метафизике идеално је решење тако постављеног проблема - Све знање је увек унапред обухваћено у свакој перцепцији сваке монаде, врлином њиховог метафизичког устројства. Бесконачна могућност сазнања налази се унутар сваке монаде: начин посматрања свеукупности идеја је различит, али диспозиције су исте - јер морају да се преклапају са божанским. Ово се јасно да ишчитати из до сада реченог, поље виртуалности, монада, на известан начин, дели са свим осталим монадама, па тако и са божанском монадом. Лајбницова мисао у потпуности подупире овакав закључак: „Може се, штавише рећи, да свака супстанција на одређени начин скрива у себи карактер бесконачне мудрости и свемоћи божије и да га, колико је она за то способна, и опонаша. Сви су, наиме, догађаји универзума, прошли, садашњи и будући у њој изражени, премда само збркано, у чему има нека извесна сличност с бесконачном свешћу и бесконачном спознајом."26 [курзив А. О.]

Смемо ли ово бескрајно поље виртуалности назвати меморијом? Односно, да прецизније формулишемо питање, да ли Лајбниц употребљава појам меморије са овим значењем?

${ }^{23}$ Lajbnic, G. V., Novi ogledi o ljudskom razumu, prevod: Milan Tasić, „,Veselin Masleša“, Sarajevo, 1986., стр. 61-67.

${ }^{24}$ Исто, стр. 65.

${ }^{25}$ Leibniz, Gottfried Wilhelm, Philosophical papers and letters, стр. 77

${ }^{26}$ Leibniz, G. W., „Rasprava o metafizici“, y: Izabrani filozofski spisi, стр. 117. 
Увидећемо да је одговор позитиван, и нема сумње да се такво виђење наслања на оно из мита о Мнемосини. Ћерка Гее и Урана и мајка свих музи, јесте она која све зна. ${ }^{27}$ Свет је у потпуности развијен унутар њеног памћења, прошлост, садашњност и будућност су, као и код Лајбница, обухваћени. Таква поставка отвара бројне промене у односу на уобичајено разумевање сећања присутно и данас, а које затичемо још код Аристотела. Без залажења у дубљу анализу, излажемо само основну идеју: реч је наиме, о дискурзивном знању, о процесу доказивања које неко сазнање потврђује као знање. Традиционално, што и Лајбниц прихвата, валидни закључак добија се спајањем две или више исправних премиса. Премисе, међутим, за Лајбница нису ништа друго, доли идеје које смо актуализовали; стога је веза између премиса пре свега за Лајбница веза међу идејама. Премда уочавање ових веза, које омогућују сазнање, врши разум, та делатност разума омогућена је управо меморијом, јер управо је меморија та којој разум мора да приступи како би уопште могао да сазнаје. Тако, меморија и у овом случају представља конституент сазнања, односно услов могућности доласка до истог. ${ }^{28}$ Међутим, чак и ово „једноставније“ разумевање меморије отвара питања која увиђа и Аристотел - попут оног „Шта је уопште то што се 'враћа' односно 'призива' у памћење“, или делезовски, шта је то, што се репрезентује?

Ипак, пре неголи пређемо на поменуте проблеме потребно је претходно испитати места у Лајбницовим списима где су присутни термини „меморије“, „памћења“ и „присећања“ , како бисмо увидели да ли је уопште могуће објединити их.

27 Погледати: Hesiod, Teogonija, prevod: Marko Višić, ITP „Unireks“, Podgorica, 2008.

${ }^{28}$ Погледати: Popović, Una, „Leibniz on memory and reason“, u Series: Philosophy, Sociology, Psychology and History, Facta Universitatis, Vol. 16, No 3, 2017, pp. 201-212 https://doi.org/10.22190/FUPSPH1703201P. 


\section{КОНЦЕПТИ МЕМОРИЈЕ У ЛАЈБНИЦОВИМ ТЕКСТОВИМА}

Лари М. Јоргенсен у свом тексту Leibniz on memory and consciousness сматра да Лајбниц разликује три различита типа меморије $^{29}$. Ми смо пре сагласни са уобичајеним Лајбницовим маниром, разликовања ширег и ужег значења, које он помиње када говори о меморији (али и о знањ $\mathrm{y}^{30}$ ); али, анализирајмо прво места на којима се јавља ова дистинкција.

Најпре: „Меморија је перцепција сопствене перцепције.” Ово једноставно одређење меморије, које је више психолошког типа, очигледно се не поклапа са нашим пређашњим одређењима меморије, па тако ни са неким наводима Лајбница која смо раније цитирали, јер уколико је меморија перцепција перцепције, то значи да је она сужена само на оно актуално у мислима, односно на самосвест. Ово је дефиниција из 1680. године, када Лајбниц још није развио своју монадолошку концепцију, али без обзира на то, као што примећује и Јоргенсен, Лајбниц на овом месту не прави дистинкцију између рефлексије и меморије коју ће, како ћемо видети, начинити касније. Постоје, међутим, и каснији наводи, које, уколико их надовежемо на ову дефиницију, иду у прилог пређашњим увидима. Такав је између осталих садржан у писмима Арноу из 1986: „Не постоји снажнија демонстрација, не само да су наше душе неуништиве, већ и то што она увек чува у својој природи трагове свих својих претходних услова са виртуелном меморијом (souvenire virtual) која се увек може пробудити јер душа има свест, или у себи зна оно што свако назива 'ја'. То је оно што је чини способном за моралне квалитете, казну и награду, чак и после живота, јер би без памћења бесмртност била бескорисна.”32

\footnotetext{
29 Jorgensen, M., Larry, „Leibniz on Memory and Consciousness“, British Journal for the History of Philosophy,19:5, 2011., стр. 887-916. DOI: 10.1080/09608788.2011.599568890

${ }^{30}$ Lajbnic, G. V., Novi ogledi o ljudskom razumu, стр. 315.

${ }^{31}$ Leibniz, G. W., „Rasprava o metafizici“, y: Izabrani filozofski spisi, стр. 126.

${ }^{32}$ Leibniz, G. W., „Pisma Arnauldu, 1686, 14. jul“, u Philosophical papers and letters, ed. Loemker, стр. 337.
} 
Много је речено на овом месту, а најзначајније је да „се сва пређашња стања” душе називају „виртуалном меморијом“. Такав став је већ у сагласју са тезом рада када је реч о памћењу код Лајбница, односно о виртуалној меморији. Уз то, Лајбниц и овде говори о бесмртности и неуништивости душе (тема о којој је много расправљао са Арноом). Упоредимо ли ово са пређашњим цитатом, допушта нам се једна надоградња која први цитат чини јаснијим меморија је могућност да се има перцепција перцепције, а не сама та перцепција, јер Лајбниц каже „која увек може бити пробуђена”, а не да увек јесте пробуђена. Јер, све и да нема акта рефлексије, свака супстанција (монада) би перципирала сва своја стања (а судећи по каснијој Монадологији, и стања свих осталих супстанција), те би стога имала виртуалну меморију. ${ }^{33}$

Следећа места из Нових огледа о људском разуму поново нас воде ка тумачењу Лајбницовог концепта меморије за које се залажемо: „Али се чудим што вам није пало на ум да ми поседујемо безброј различитих знања која не опажамо увек, чак ни онда када имамо потребе за њима. Улога памћења (memoire) јесте да их чува, a cећања (reminiscence) да их износи, што често, али не увек, и чини по потреби. ${ }^{\text {34 } С л и ч н о ~ т о м е, ~ ч и т а м о: ~ „ П о ш т о ~ с е ~ н е к о ~ с т е ч е н о ~ з н а њ е ~}$ може сакрити памћењем, као што признајете да може, зашто природа такође не би могла сакрити неку јединицу неодређеног знања?" 35

33 Исто примећује и Јоргенсен: "But any substance that does not have reflection would still have traces of all its preceding states, and in this sense would have a virtual memory” Jorgensen, M. Larry, „Leibniz on Memory and Consciousness", British Journal for the History of Philosophy, стр. 891.

${ }^{34}$ Lajbnic, G. V., Novi ogledi o ljudskom razumu, стр. 37. Сматрамо да би исправнији превод био ,...а сећања, да их ставља опет пред нас “.

35 „Јер, с обзиром на то да стечено знање може памћењем бити сакривено у души, што признајете, зашто не би било могућно да је природа једнако сакрила у себи извесно изворно знање". Lajbnic, G. V., Novi ogledi o ljudskom razuти, стр. 39. 
Лајбниц овде, попут Аристотела ${ }^{36}$, јасно раздваја присећање и памћење, или меморију, јер, судећи по овом, пример меморије из првог наведеног цитата овде би се односио на памћење - меморија је свеукупност перцепција, присећање је процес у којем то перципирано постаје и свесно. Дакле, чак и да присећање изостане (перцепција перципираног), све перцепције (читав универзум) се и даље складиште у меморији. Приметимо сада прелаз који је видљив на основу другог цитата; уколико је стечено (актуализовано) знање сачувано у меморији, Лајбниц пита зашто у њој не би било складиштено и изворно знање које је природа усадила (поставила) у нас. Другим речима, актуално знање није урођено, ,али је урођено оно што можете назвати потенцијалним знањем"37 - ми управо за тим посежемо, када покушавамо да актуализујемо знање - за меморијом. Поврх тога, меморија коју ,је природа сакрила у нас" дословно значи виртуална меморија, узимајући у обзир латинско значење речи виртуално. Другим речима, поседовање идеја унутар перцепције, те наша могућност да их призовемо у свест, не зависи од рефлексије истих, односно од тога да ли их тренутно и актуално промишљамо. Исто важи и за меморију. Имати меморију не значи нужно користити је, како би се призвало нешто из ње, она је већ увек присутна и независна је од наше актуализације њеног садржаја: све-могућа диспозиција свеукупног знања је присутна унутар ње, и све монаде га одувек поседују.

У наведеним цитатима веза меморије и знања показује се путем њиховог метафизичког устројства - начином на које све деле садржај који перципирају и начин на који су њихове перцепције међусобно усклађене (престабилираном хармонијом). У складу са реченим, обратимо пажњу на разлику између првог цитата у ком се помиње меморија и осталих који следе. Наиме, премда Лајбниц каже да је „Меморија перцепција своје перцепције”, јасно видимо

36 Упореди са: Aristotle, „De Memoria et Reminiscentia“, u: Aristotle on Memory and Recollection, preveo: David Bloch, Brill, Leiden - Boston 2007. 449b4 str. 25.

${ }^{37}$ Lajbnic, G. V., Novi ogledi o ljudskom razumu, стр. 39. 
касније да је меморија присутна и када се не долази до „перцепције перцепције". У вези са овим, сматрамо да ову разлику треба разумети као ужи и шири концепт меморије, те да није реч о неспојивој разлици значења. Када кажемо „ужи и шири” концепт, користимо Лајбницову терминологију из Нових огледа: оно што би се мислило под тим јесте да „уже” реферише на употребу меморије, односно на конкретне тренутке када се меморија актуализује, док би „шири” појам меморије упућивао на memoire virtual или souvenire virtual, метафизичку концепцију меморије унутар које је ускладиштено бескрајно потенцијално знање. Тако се, по поставци монадолошког света, знање базира на овим одређењима меморије. Дакако, погледајмо још нека места која нам говоре да је нераскидива повезаност знања и меморије присутна и унутар „ужег” појма меморије (који подразумева самосвест).

Лајбниц тврди: „нема знања или резоновања без лика, јер се све резоновање или демонстрација одвија кроз памћење премиса". Такође и на следећем месту: „Када монада има органе који су на тај начин подешени, кроз њих постоји контраст и разлика међу утисцима које добијају, а самим тим и контраст и разлика у перцепцији која их представља (у монади), онда то може довести до сензације, односно перцепције праћене меморијом...”38 И даље: „Памћење пружа неку врсту последичности (секвенцијалности) душама, која подражава ум, али која се од њега мора разликовати." ${ }^{39}$

Ова места враћају нас на почетак поглавља, где смо говорили о процесу закључивања и о повезивању перцепција или идеја: ја морам моћи задржати идеје унутар свог ума, како бих уопште имао могућност да их повежем, а знање, како ћемо видети, управо почива на везама. Други цитат нам говори да је разлика представљања, заправо, само разлика јасноће перцепције; пошто се

\footnotetext{
${ }^{38}$ Leibniz, G. W., Principles of nature and Grace G VI 602, цитат преузет из: Jorgensen, M., Larry, „Leibniz on Memory and Consciousness“, British Journal for the History of Philosophy, стр. 894.

${ }^{39}$ Lajbnic, G. V., Monadologija,, стр. 52.
} 
перцепција јавља као идеја, тако је и свака чулна сензација, као идеја, базирана на функцији меморије. Управо разлика у нивоу перцепције на монадолошком нивоу, захтева опрез када је реч о разликовању меморије и разума на које Лајбниц позива: Ми „усмеравањем пажње”, истраживањем, путем чулних утисака „откривамо” (постајемо свесни) идеје, тако што увећавамо ниво перцепције исте, а то радимо када уочавамо везе између идеја. Али мноштво идеја (које су у меморији) већ се путем престаблиране хармоније налазе у односу који подразумева бесконачан број веза које оне граде. Јасноћа перцепције нам не дозвољава да увек уочимо ове везе, заправо, само мали број веза (веза које нам допуштају да изнесемо закључке) и можемо да уочимо. Зато није довољно само рећи да разум врши закључивање - у нашој меморији су идеје, али неке од тих идеја су унутар нас на крајње нејасан начин, што, уосталом, јесте одлика човека (и свих осталих монада осим Бога). „Ја морам да имам тело, пошто су унутар мене нејасне идеје" ${ }^{\prime 4}$, рећи ће Делез, пратећи Лајбница. Меморија, дакле, можда омогућује приступ идејама, а јасноћа истих јесте задатак разума, а тек из ове јасноће расте увиђање веза које су есенција знања.

\section{НАСЛЕЂЕ „ПАМЋЕЊА“: ИЗМЕЪУ МНЕМОСИНЕ И АРИСТОТЕЛА}

Имајући у виду изразито обимну литературу посвећену искључиво Платоновом или Аристотеловом поимању меморије, а да не помињемо оне анализе које укључују и друге ауторе, односно концепције, јасно је да овакав вид поређења не може пружити никакве иоле исцрпне и детаљне увиде. Намера је пак, да се контурама различитих теорија о меморији адекватније истакне значај Лајбницове мисли, и промена перспективе која је у тој мисли присутна, јер без тих, ма како базичних увида, одређени аспекти Лајбницове виртуалне меморије остају неуочени.

${ }^{40}$ Delez, Žil, Nabor, Lajbnic i barok, cтр. 161. 
Текст који заступа тезу о урођеним идејама, до којих се долази истраживањем сопствене свести (дакле неком врстом присећања) не може избећи референцу на спис који представља један од „камена темељаца“ таквог става, унутар филозофског дискурса. Реч је наравно о Платоновом Менону, којег Лајбниц спомиње већ на самом почетку Нових огледа. ${ }^{41}$ Без сумње да овај дијалог, заједно са бројним истраживањима која упућују да се кључ за његово читање налази у орфичком миту (али и обрнуто) ${ }^{42}$, говори у прилог концепцији виртуалне меморије. ${ }^{43}$ Међутим, да бисмо дошли до сличности, потребно је, како смо наговестили, прво осврнути се на оне теорије о меморији које истичу разлику - те се управо стога окрећемо ка Аристотелу.

Оно што у одређеној мери олакшава посао, јесте чињеница да је Аристотел проблему меморије посветио посебан спис под називом De memoria et reminiscentia ${ }^{44}$, премда је аргументација изнесена у овом делу често у спрези са местима из других текстова, пре свих Аналитика или $O$ души. Ипак, већ на самом почетку $D e$ memoria Аристотел излаже увиде који су нам у овом раду од главног интереса: „С обзиром на меморију и памћење, морамо изрећи шта су и који су разлози њиховог појављивања, као и у ком делу душе се јављају; а морамо исто то урадити и када је у питању присећање, јер људи који су добри у памћењу нису исти они који су добри у присећању.“45Дакле, одмах уочавамо да постоје три

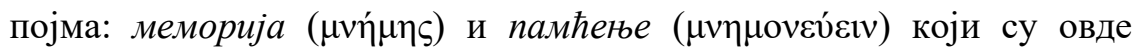
сврстани у један заједнички корпус, и са друге стране присећање

${ }^{41}$ Lajbnic, G. V., Novi ogledi o ljudskom razumu, стр. 38

${ }^{42}$ Видети између осталог: Dinkelar M, Bjanka, „Plato and the Language of Mysteries: Orphic/Pythagorean and Eleusinian Motifs and Register in Ten Dialogues" u Mnemosyne: Journal of classic studies, 73 (2020) 36-62.

${ }^{43}$ И поред суптилних разлика које ће Лајбниц истаћи на страници 39 Novih ogleda, али које се пре односе на начин на који су идеје „урођене“, а не на саму поставку „урођености“, те стога нису релевантне у овом моменту.

44 У даљем тексту: De memoria

45 Aristotle, „De Memoria et Reminiscentia“, u: Aristotle on Memory and Recollection, preveo: David Bloch, Brill, Leiden - Boston 2007.449b4 str. 25. Превод на српски: Остојић А. 
$(\alpha v \alpha \mu \mu \nu \eta \sigma \kappa о \mu \alpha l)$, за које, као што видимо, тврди да се разликује од памћења. Лајбниц ће на многим местима пратити ову, за тумачење незахвалну појмовну дистинкицију. Да бисмо приступили анализи или брижљивијем излагању ових нијансираних дистинкција, потребно је одмах увести и друго важно место из De memoria: „Меморија је стога, нити осет, нити концепт, већ стање или афекција која произилази из једног од ова два, након што је неко време протекло. Као што смо рекли, нема меморије о сада у садашњем тренутку. Јер у садашњости је осет, у будућности је очекивање, а у прошлости је меморија. Стога се сва меморија дешава у времену. “46

Меморија је дакле, не осет, јер је осет оно што се дешава у садашњем времену, већ стање проузроковано осетом, али које подразумева да је неко време од непосредног осета протекло. Меморија је тако без сумње повезана са перцепцијом, али, као што и за Лајбница она остаје на општој или „несвесној“ перцепцији, тако је и код Аристотела више разлога зашто она не може да буде разумска перцепција, односно перцепција разума. Најпре, Аристотел ће рећи да постоје животиње које могу да имају меморију, а услов за то је да имају осећај о времену. ${ }^{47}$ Добро је познато да је, за Аристотела, једина животиња која има разум управо човек. Да је меморија разумска активност, односно водећи се Аристотеловом терминологијом, да је то активност која припада разумском делу душе, не би постојала могућност да ма која животиња може да има меморију. Стога је Аристотел на неки начин принуђен да способност меморије припише осетилном делу душе. Али, посреди је још један, јачи разлог исказан на већ чувеном месту списа $O$ души: „мишљење није могуће без представе“48 рећи ће Аристотел. Представа овде јесте слика (ментална), односно

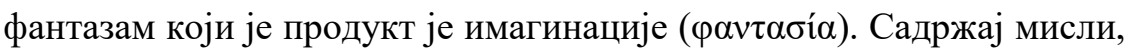

\footnotetext{
${ }^{46}$ Исто, стр. 27, превод и курзив: Остојић А.

${ }^{47}$ Исто, стр. 29.

${ }^{48}$ Aristotel, O Duši, Parva naturalia, prevod: Slobodan Blagojević, PAIDEIA, Beograd, 2012., str. 278.
} 
ма како апстрактан био, увек се изражава путем слике, тврди Аристотел. Та слика јесте оно што афицира чула, а у случају памћења, ово произвођење слике јесте управо вид оприсутњавања објекта памћења који је одсутан, а меморија омогућава да ова ментална слика која ре-презентује одсутни објекат, на исти начин афицира чула у датом моменти (у садашњости) као што је „прави“ објекат учинио у прошлости. Одатле за Аристотела следи да је меморија на првом месту везана за реафекцију чулности, односно за чулност: „Стога, меморија ће тек акцидентално припадати разуму, а суштински и примарно чулности.“49 Два су дакле разлога у Аристотела да меморију припише осетилном делу душе. Нећемо на овом месту улазити у бројне проблеме и питања које ове поставке отварају, од теорија имагинације до природе „правог“ објекта код Аристотела, оно што нас пак у одређеној мери занима, јесте шта је то унутар меморије што остаје или што се враћа, јер оно чега се сећамо није присутно у садашњости, те да ли је време овде неопходан фактор? Ипак, пре него сумирамо речено, сада када смо изложили Аристотелово виђење меморије, пређимо на присећење.

Присећање није памћење, нити меморија ${ }^{50}$, већ настаје онда када „кретање, следи неко друго кретање “51. О каквом кретању је реч? Када се присећамо, ми смо „покренути“ или подстакнути неким пређашњим тренуцима, и при том, није реч о једној кретњи, већ једна афекција покреће другу, једна кретња покреће другу, све док не дођемо до стања које желимо да се јави. ${ }^{52}$ Дакле, код Аристотела, меморија и памћење јесте начин на који у чулима остаје афекција изазвана од стране објекта памћења, док је

\footnotetext{
${ }^{49}$ Исто, стр. 29.

50 Аристотел наводи неколико примера на којима извлачи разлике, ми ћемо овде прескочити анализу разлика, јер сматрамо да ће се кроз одређење појма разлика сама предочити.

${ }^{51}$ Исто, стр. 39, курзив аутор.

52 Ова кретања се одвијају унутар душе, а Аристотел нимало не запоставља њихову улогу у могућности доласка до знања о универзалном. Погледати: Griford, Mark, „Aristotle on Platonic Recollection and the Paradox of Knowing Universals: "Prior Analytics"“, y: Phronesis, Brill, Vol. 44, No. 1 (Feb., 1999), str. 1-29.
} 
присећање изазивање кретњи које ће на крају водити до тражене афекције. Изазивање тих кретњи врши разум, па тако чин присећања припада за разлику од памћења, разумском делу душе.

Премда је, како је већ речено, ова појмовна дистинкција присутна и код Лајбница, Аристотел за разлику од њега нема шири и ужи концепт меморије или присећања. Да се изразимо прецизније, премда их разликује, Аристотел све време говори искључиво о меморији и присећању као о тпете, а никако као anamnesis односно, његово објашњење, барем на овом месту, усмерено је на сећање као психолошки чин, али и на његову онтолошкомитолошку димензију, на присећање као на делатни чин духа, као место које конституише однос индивидуе и света као код Лајбница, на anamnesis као praxis по речима Рикера. ${ }^{53}$

Сумирајмо сада у којој мери Лајбницова концепција меморије одудара од Аристотеловог виђења исте, служећи се митолошком идејом Мнемосине. Унутар Мнемосине сједињени су прошлост, садашњост и будућност, другим речима обухваћен је читав Свет - она је та која све зна, Свет је са својим законима и у својим јављањима потпуно развијен унутар ње, унутар њене меморије. На исти начи, свет је, можда не развијен, али свакао увијен унутар Лајбницове монаде. Покушавајући да реши нововековни, али и антички проблем односа индивидуалитета супстанцијалитета и тоталитета, Лајбниц се надовезује на старо учење о преклапању микро и макрокосмоса, надограђујући га: „Он индивидуалитет узима као тоталитет, не као оно коначно које је напросто различито, него као оно што је бесконачно у разлици, као бесконачност индивидуалних тоталитета - монада“"54. Виртуална меморија је Мнемосинина меморија, али за разлику од грчког мита, свет унутар монаде је бесконачан, па је и поље меморије за Лајбница бесконачно. Присећање је увек код Лајбница anamnesis -

53 Видети Рикерова поглавља о Платону и Аристотелу у: Riker, Pol. Memory, History, Forgetting, prevod: Ketlin Blejmi i Dejvid Peluer, Chicago: University of Chicago Press, 2004. str. 7-21.

${ }^{54}$ Perović, M., „Lajbnicova metafizika“, u Filozofske rasprave, biblioteka "Filozofska istraživanja", Hrvatsko filozofsko društvo, Zagreb 2011., str. 63. 
делатни процес обухватања начина на који се свет јавља, који никад сем у случају врховне монаде није транспарентан (што је још једна разлика у односу на грчки мит).

Са друге стране, као и код Аристотела, присећање је кретање, унутар сопства, унутар душе ${ }^{55}$, али сада стижемо до кључне разлике спрам претходних меморијских концепција рачунајући и Аристотелову: код Лајбница шири, односно онтолошки концепт меморије и присећања неме никакве везе са временом. Ово је огромна промена, јер је за цео средњи век као и за Аристотела, време основни предуслов памћења. Међутим, није реч о томе да је памћење код Лајбница независно од времена, већ заправо говорећи, време не постоји, свакако не на начин на који га традиција разумева. Као што Перовић примећује, монада је бесконачни тоталитет разлика - изрази унутар душе, јесу различити изрази света, различита стања душе, јесу различита стања у којима свет постоји, и њих је бесконачно. Виртуална меморија обухвата ову бесконачну потенцију, али присећање као унутрашње кретање унутар монаде или унутар света, није потрага за другим временом, већ за другим местом - toposom. Сећање се увек бави местима, а ако су, као код Лајбница, будућност и прошлост бременити и испреплетани међусобно, време губи своје онтолошко утемељење, оно само је само још један израз душе, који произилази из виртуалне меморије. ${ }^{56}$ У складу са тим, за Лајбница су, као и за Платона, питања „шта је то што се враћа присећањем, када објекат остаје одсутан“, и „како ментална слика замењује објекат“ много лакше решива него за Аристотела. Ништа се не враћа, све је већ у

\footnotetext{
${ }^{55}$ Aristotle, „De Memoria et Reminiscentia“, str. 39-41.

56 Свакако да је Лајбницово поимање времена тема која захтева више од ових пар преченица, али за наш приказ довољно је поред наведеног додати следеће: Време по себи претпоставља два система - на основу учесталости кретања/промена у једном ми меримо кретање/промене у другом. Свако обухватање или прецизније мерење, подразумева суптилнији механизам изван самог система. Али уколико је све један тоталитет, као што је реч о монади, не остаје ништа изван система, што би допустило постојање времена унутар њега - Као и у Лајбницовој меморији, време постаје излишан појам.
} 
души, у супстанцијалитету, само смо сада у стању да перципирамо место које је раније било на мрачном дну виртуалности. Знање се налази у местима у меморији, та места се разликују међусобно, али су обухваћени тоталитетом монаде - способност Мнемосине, Лајбниц преноси на човека, али космолошка слика се променила. Та способност пред собом више нема затворени, коначни свет, већ (од Ђордана Бруна) бесконачни отворени Универзум. Та промена, захтевала је и промену приступа: Anamnesis је код Лајбница у пуној мери оживљен и поновно постаје делатни чин доласка до знања, са тим да му је природа измењена, јер присећање пред собом више нема затворену целину, већ бескрајни скуп актуалног и потенцијалног - souvenir virtual.

Показали смо да се у оба случаја, и метафизичком и епистемолошком, меморија испоставља као услов могућности сазнања, али и као главни конституенс на ком почива Лајбницово преклапање микро и макрокосмоса, односно монаде и света. На тај начин се и усмерава пажња на разумевање виртуалне меморије код Лајбница, појма који је често био запостављен унутар студија које су се за предмет проучавања имале Лајбницову филозофију.

У другом делу рада, терминолошком анализом, у раду смо истражили различите називе које Лајбниц употребљава за меморију и различите функције које тим називима жели да именује. Управо ту, показује се да је souvenir virtual проблематично превести са памћење, јер је то само једно од бројних функција виртуалне меморије. Тако и присећање (reminiscence) није нужно пут у прошлост. Иако чињеница да Лајбниц није систематично разложио функције унутар појма меморије, успели смо да сва значења која се јављају у Лајбницовим текстовима обухватимо унутар нашег разумевања виртуалне меморије.

На крају смо се суочили са традицијом, и фокусирајући се на Аристотелово разумевање меморије и присећања подвукли разлике и новине које Лајбниц уводи, сједињавајући поимање 
меморије античке Грчке са нововековном променом перспективе. Као што смо показали, меморија је „складиште” из којег се виртуалност света извија, могућност да се приступи бесконачном знању. Не треба да буде забуне, усмереност на меморију нипошто не представља сећање на прошлост. Сећање мења значење, меморија се више не посматра као складиштење старог (знања), већ као могућност да се види, спозна ново. Платонов Менон је избор фигуре која симболише тај поступак, зато га и Лајбниц користи, али наравно, не разумева га дословно, односно није у потпуности сагласан са њим: „Платоничари су мислили да су сва знања сећања и да зато истине које душа доноси с рађањем човека, зване урођене истине треба да буду остаци ранијег јасног сазнања. Али је ово мишљење потпуно неосновано и лако се показује како је нужно да душа већ има урођена сазнања у извесном претходном стању, ма колико далеко оно било, управо као и у садашњем стању." 57

Тако понирање у виртуалну меморију није пут уназад, већ пут у потенцијалну свеукупност знања, у биће монаде, чија непрекидна динамичност омогућује да се за нас стално и изнова јавља ново знање.

\section{ЛИТЕРАТУРА}

Aristotel, O Duši, Parva naturalia, prevod: Slobodan Blagojević, PAIDEIA, Beograd, 2012.

Aristotle, „De Memoria et Reminiscentia“, u: Aristotle on Memory and Recollection, preveo: David Bloch, Brill, Leiden - Boston 2007.

Delez, Žil, Nabor: Lajbnic i barok, Fedon, Beograd, 2018.

Dinkelar M. Bjanka, „Plato and the Language of Mysteries: Orphic/Pythagorean and Eleusinian Motifs and Register in Ten Dialogues" u Mnemosyne: Journal of classic studies, 73 (2020) 36-62.

Griford, Mark, „Aristotle on Platonic Recollection and the Paradox of Knowing Universals: "Prior Analytics"“, y: Phronesis, Brill, Vol. 44, No. 1 (Feb., 1999), str. 1-29.

Hesiod, Teogonija, prevod: Marko Višić, ITP „Unireks“, Podgorica, 2008.

${ }^{57}$ Lajbnic, G. V., Novi ogledi o ljudskom razumu, стр. 39. 
Jorgensen, M., Larry, „Leibniz on Memory and Consciousness“, British Journal for the History of Philosophy,19:5, 2011., стр. 887-916. DOI: 10.1080/09608788.2011.599568890

Lajbnic, G. V., Novi ogledi o ljudskom razumu, prevod: Milan Tasić, „Veselin Masleša“, Sarajevo, 1986.

Lajbnic, G. V., Monadologija, prevod i komentari: Dušan Nedeljković, Kultura, Beograd, 1957.

Leibniz, G. W., Izabrani filozofski spisi, Naprijed, Zagreb, 1980.

Leibniz, G. W., Philosophiscen Schriften, edited by: Gerhardt, C. I., vol. 7, Hildesheim, Berlin, 1965.

Leibniz, G. W., „Letters to Arnauldu, 1686, 14. july“, u Philosophical papers and letters, ed. Loemker, Dodrecht: Reidel, 1979.

Leibniz, Gottfried, Wilhelm, Philosophical papers and letters, (ed. Leroy Loemker), Dodrecht: Reidel, 1979.

Mates, Benson, The philosophy of Leibniz, Metaphysics and Language, Oxford University press, New York, 1986.

Milenković, Ivan, „Predgovor“, u: Delez, Žil, Nabor: Lajbnic i barok, Fedon, Beograd, 2018.

Perović, Milenko, „Lajbnicova metafizika", u Filozofske rasprave, biblioteka "Filozofska istraživanja", Hrvatsko filozofsko društvo, Zagreb 2011.

Popović, Una, „Leibniz on memory and reason“ u Series: Philosophy, Sociology, Psychology andHistory, Facta Universitatis, Vol.16, No3, 2017., str. 201-212, https://doi.org/10.22190/FUPSPH1703201P

Popović, Una, „Logika ideja: Por Rojal i Dekartovo nasleđe“, y: Годишъак Филозофског факултета у Новом Саду, стр. 49-66. 


\title{
ALEKSANDAR OSTOJIĆ
}

University of Belgrade, Institute for Philosophy and Social Theory / University of Novi Sad, Faculty of Economics in Subotica

\section{LEIBNIZ AND SOUVENIR VIRTUAL}

\begin{abstract}
This paper seeks to examine Leibniz's concept of virtual memory, and to determine its role within the monadological conception of the world. Leibniz's notion of memory is certainly ambiguous, which will be seen in the paper, through the explication of places in Leibniz's texts, in which memory is differently defined. More precisely, we will see that Leibniz distinguishes different functions within the notion of memory, and accordingly names them differently, yet they are all encompassed within virtual memory, which forms both the ontological and epistemological basis of the Leibniz universe. In the first part of the paper we will outline the principled monadological settings and the reasons why virtual memory has a large share in them. In the second part, we will examine the places in which Leibniz writes about memory, seeking to unify them within our understanding of virtual memory, in addition to the differences that exist between these definitions. For us to be able to adequately emphasize importance of Leibniz approach to concept of memory, it will be necessary to confront his understanding with that of the tradition, especially focusing on Aristotle. Finally, we will see why such a Leibniz memory setting, we suppose, is necessary to increase knowledge in any way.
\end{abstract}

Keywords: Leibniz, memory, monadology, reminiscence, virtual, knowledge, Aristotle

Primljeno: 2.5.2021.

Prihvaćeno: 5.7.2021. 